\title{
Influence of speech breathing after physical activity on intonational-pausal segmentation of speech
}

\author{
Belkova Lubov \\ Lomonosov Moscow State University \\ belckowa.leyandex.ru
}

\begin{abstract}
This study raises the problem of the difference between normal and forced (deep) speech breathing. The aim of this work was to study the intonational-pausal segmentation of speech in normal and forced breathing after physical activity. The results of the study show that in the process of reading, the structure of the text determines the organization of breathing, and the breathing rate and respiration depth have an impact on the intonational-pausal segmentation of speech, as well as on the duration and quantity of intonation pauses.

Keywords: phonetics; breathing pause; text localization; intonational-pausal segmentation; forced breathing
\end{abstract}

DOI: $10.28995 / 2075-7182-2021-20-94-109$

\section{Влияние речевого дыхания при мышечных нагрузках на интонационно-паузальное членение речи}

\author{
Белькова Любовь \\ Московский Государственный \\ Университет им. М. В. Ломоносова \\ belckowa. leyandex.ru
}

\begin{abstract}
Аннотация
В данном исследовании поднимается вопрос о различии обычного и форсированного (глубокого) речевого дыхания. Целью работы явилось исследование интонационно-паузального членения речи при обычном и форсированном дыхании после физической нагрузки. Результаты исследования показывают, что при чтении структура текста определяет организацию дыхания, а частота и глубина дыхания влияют на интонационнопаузальное членение речи, длительность и количество интонационных пауз.

Ключевые слова: фонетика; дыхательная пауза; текстовая локализация; интонационно-паузальная сегментация; форсированное дыхание
\end{abstract}

\section{Introdaction}

\subsection{Breathing: normal and forced}

Breathing is a process consisting of three stages: 1) external respiration; 2) transport of gases by the circulatory system; 3 ) internal respiration. For the body processes the cells must receive oxygen and emit carbon dioxide - this is how energy is released.

External respiration provides lung ventilation that maintains a constant concentration of oxygen and carbon dioxide in the alveolar air [4].

The respiratory cycle consists of the inspiratory and expiratory phases. During inspiration (which is an active process), the muscles contract, the diaphragm raises the lower ribs, thereby the chest capacity increases. Expiration is a passive process: the muscles relax and the diaphragm descends.

Forced breathing (FB), i.e. deep breathing, differs from normal breathing (NB). FB can be associated with psycho-emotional or physical stress. During muscular exercise, a person needs more oxygen and 
thus the tidal volume increases owing to the need to satisfy the metabolic needs of the body. In the forced inspiration, the muscles of the back and neck, rotator cuff, and facial muscles also take part. The chest capacity increases even more compared to a normal inhale. Forced exhalation is also an active process, by contrast with the normal inspiration, since the lung ventilation should be carried out faster; the air is sharply released by the means of auxiliary muscles.

During NB, about $1 \%$ of the oxygen consumed by the body is spent on the work of the respiratory muscles; during physical exertion and $\mathrm{FB}$, the energy consumption for lung ventilation increases to $20 \%$. Thereat, in both cases, the breathing mode (frequency and depth) is carried out involuntarily, depending on the physical feasibility of the body [15].

\subsection{Breathing and speech}

There is a distinction between physiologic and speech breathing [5]. In physiologic respiration, the inhale is equal in duration to the exhalation. The frequency of inspirations for adults is $16-18 \mathrm{p} . \mathrm{m}$. In the setting of muscle load, the frequency of inhales can reach $40-60$ p.m. During speech breathing, the inhale accelerates, and the exhale slows down significantly. The amount of inspiratory air can increase by 3 times compared to the physiological exhalation [2].

Speech breathing is associated not only with the production of sounds, but also with the formation of rhythmic-intonational segmentation of speech. In modern phonetics, it is considered that breathing passively adjusts to intonation pauses (IPs) [6]. A pause is usually understood as a break in articulation and, consequently, a break in the speech signal. Such pauses can be described as temporal (TPs - they are realized by a segment of zero intensity in the signal). Moreover, in the absence of a physical pause (NTP - non-temporal pause) as a pause can be interpreted a sharp change in tone and other prosodic parameters [7]. A pause in speech is often used for inhaling, but this does not mean that it necessarily occurs because of the physiological need. A person in a calm state pauses, including in accordance with the semantic segmentation of speech [17]. Typically, pauses occur between syntactic units. The pause can be filled with an inspiration and then it is called a breathing pause (BP). A non-breathing pause (NBP) is performed without inhaling. The experimental data (Krivnova 2007 [8], Grogean/Coxtins 1979 [3], Zellner 1994 [16]) show that the preferred location of speech inspiration is the end of a sentence (in English and Russian) and the end of a clause ${ }^{1}$ (in Russian). In a number of experiments, Krivnova discovered that the hierarchical structure of text units plays an important role in the organization of speech breathing: "Text fragments are organized in descending order of the probability of the next breath in a certain way $<\ldots>$ : paragraph $(100 \%)>$ sentence within a paragraph $(94 \%)>$ clause within a sentence $(65 \%)>$ component within a clause (34\%)" [12]. At the same time, the length of the BP varies according to its textual localization: "Low PBS (Perceptual Boundary Strength) values usually go hand in hand with a short pause $<\ldots>$. High PBS values frequently imply a long pause" [13]; see also: "the mean duration of BPs and NBPs is not only a function of speaking rate but also of syntax. Both types of pauses are longer at the End S [end of sentence] location than at any other location and as the linguistic importance of the breaks diminishes, so does the duration of BPs and NBPs" [3].

In case of forced breathing, the localization, number, and type of IPs seem to vary. However, there is no evidence to support this hypothesis in the literature which is known to us.

In this regard, the main research tasks were:

1) to identify the main differences in the organization of intonation segmentation of the text while reading,

2) to analyze the coherence of TPs with the boundaries of different text units,

3) to compare the duration of TPs at the borders of different text units

during NB and FB.

\footnotetext{
${ }^{1}$ A clause is any group, including a non-predicative one, whose top is a verb, and in the absence of a lexical verb, a copula or a grammatical element that plays the role of a copula [14].
} 


\section{Material, participants and research methodology}

The material for this study was the reading of the specially constructed text. The experimental text contained 7 graphic paragraphs, 27 sentences ( 7 - simple, monoclausal; 20 - polypredicative constructions of various types), 68 clausal units that are components of sentences, and 1 utterance (see Table 1 in the Appendix 1). The text represents a textual unity with the presence of direct speech, dialogues, and expressive words.

The text after preliminary acquaintance immediately before the start of the experiment was read over from a paper sheet twice in the same sequence for everyone: first - in a normal condition and then after physical exercise. Physical activity was the same for all participants; it was achieved by quick (as possible) climbing the stairs from the 1st to the 10th floor. Each participant's heart rate was measured while reading the text before and after the exercise load. The pulse was measured by palpation of the radial artery. The average frequency of the heart rate at rest is usually 60-80 beats p.m. for healthy people aged 18 to 50. During normal breathing, the pulse of the participants was 61-78 beats p.m. After physical activity, the pulse of all informants varied from 95 to 127 beats p.m., which is typical of the frequent pulse (more than 90 beats p.m.) [1]. The text was read from a paper sheet by 8 participants, women of 18-20 years old, Russians, native speakers of literary pronunciation, students of the Faculty of Philology, but without special announcer training. Further, participants are indicated by letters of the Latin alphabet and numbers 1-2, where 1 is the reading in NB, 2 - in FB (a-1, a-2; b-1, b-2, etc.). Examples of reading the text by the same speaker with two options for pausing (in NB and FB) are represented in the Appendix 2.

The reading was recorded on a ZOOM Handy Recorder H4n using a condenser microphone.

The average duration of the sounding text was $88 \mathrm{sec}$. (73 sec. without pauses) during NB and $94 \mathrm{sec}$. during FB (72 sec. without pauses).

The type of IPs and the presence of respiratory filling in them in the voiced versions of the text were determined audibly and visually by spectrograms using the sound analyzer Praat, version 6.0.33. The duration of pauses and other speech segments was measured in semi-automatic mode using the same analyzer.

Examples of segmentation are shown in Figure 1-a - 2-a in the Appendix 3.

\section{Results and discussion}

\subsection{General phonetic pattern of IPs with different text localization during NB and FB}

Figure 1 shows the oscillograms and spectrograms of IPs with different text localization during NB. 

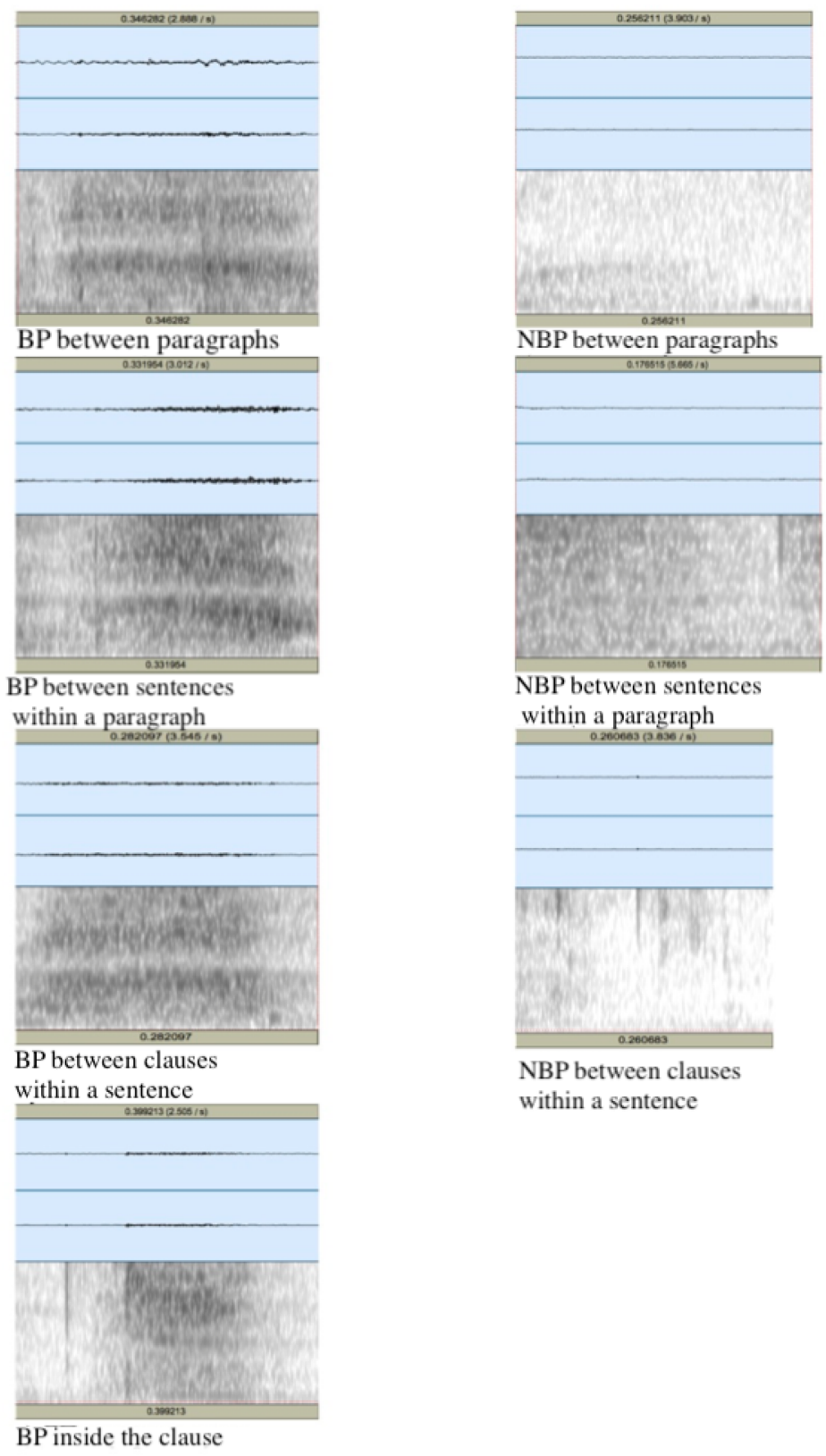

NBP between clauses

within a sentence

Figure 1: Acoustic pattern of IPs. BPs are on the left. NBPs are on the right. Pauses are represented without capturing of the adjacent sections of the speech signal. The duration in seconds is shown at the top.

As reflected by Figure 1, IPs with different text localization and content differ from each other:

1) Any BPs is characterized by four phases (see Figure 1-a in the Appendix 3): a) termination of articulation and, consequently, of the speech signal; b) a short, voiceless part, sometimes filled with a short nasal inhale or exhale; c) noisy oral (rarely nasal) inspiration and smacking, preceding it, swallowing, etc. (which are realized by an explosion, as in obstruent consonants); d) the voiceless part before resuming the speech signal.

2) BPs have a longer duration than NBPs (see 3.3).

3) Pauses are characterized by different durations depending on the hierarchical structure of the text units. However, the pause inside the clause is not subject to this pattern, perhaps due to the fact that the pause was made after the utterance $(\ni x)$ inside the clause and was perceived as a pause between sentences inside the paragraph. Such cases will be discussed below.

Figure 2 shows the oscillograms and spectrograms of IPs with different text localization during FB (text was read by the same participant). 


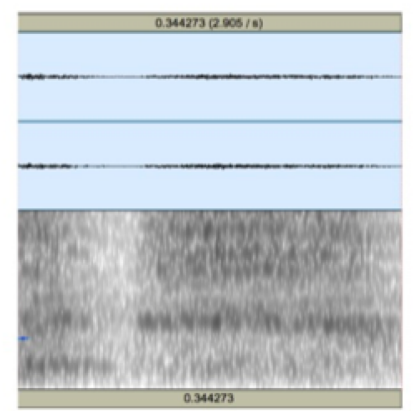

BP between paragraphs

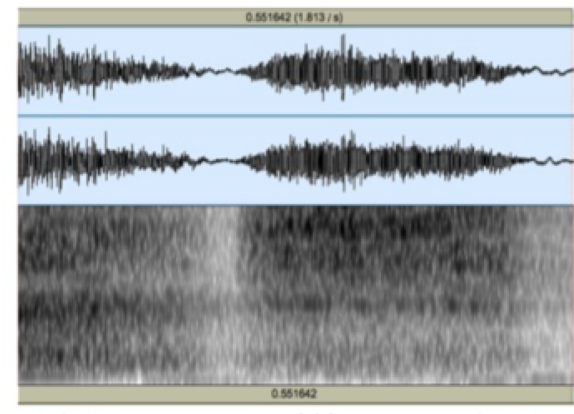

BP between sentences within a paragraph

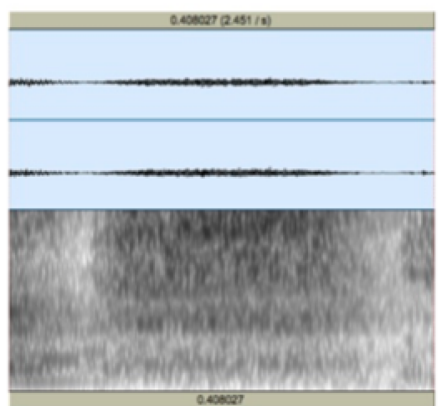

BP pauses between clauses

within a sentence

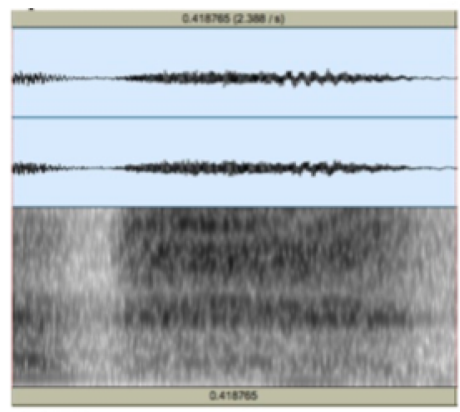

BP within a clause

Figure 2: Acoustic pattern of IPs. Pauses are represented without capturing of the adjacent sections of the speech signal. The duration in seconds is shown at the top.

Figure 2 shows only the BPs. In FB, this participant did not make NBPs. Many pauses were not realized where they were implemented before the physical exercise.

Comparison of Figures 1 and 2 allows to identify the following features of forced speech breathing:

1) The BP during FB is characterized by four phases (see Figure 2-a in the Appendix 3): a) an exhalation that is inseparable from the speech signal. Exhalation is characterized by the noise similar to the noise of the fricative [x]; b) a short, voiceless part; c) noisy oral or nasal inspiration. It ought to be noted, that during FB before inhaling, there are no smacking, swallowing, etc., because the inhale is always realized immediately after the exhalation; d) the voiceless part before resuming the speech signal.

2) The BP can be prolonged in comparison with the BP during NB, because it includes not only inhaling, but also exhaling; this pattern, however, is not always observed.

3) Inhaling is noisier than the inhaling during NB.

4) The duration of the pause does not always depend on the hierarchical structure of the text.

Thus, we can conclude that the nature of pauses is determined by the features of breathing.

\subsection{General features of speech breathing in the readings of the same text by different partici- pants during NB and FB}

The general data is given in Table 2 in the Appendix 4 and in Figures 3 and 4.

Among the most common features of speech breathing in the readings of the same text by different participants during NB and FB we can emphasize the different quantity of IPs and the difference in the speech tempo. The data was determined by the read out text, without taking into account internal TPs. Most participants read the text at an medium tempo. Average tempo speed (Lenneberg, 1967) is 5.6-6.7 syllables p.s. [11]. Thus, the duration of the syllable is $150-170 \mathrm{~ms}$. 


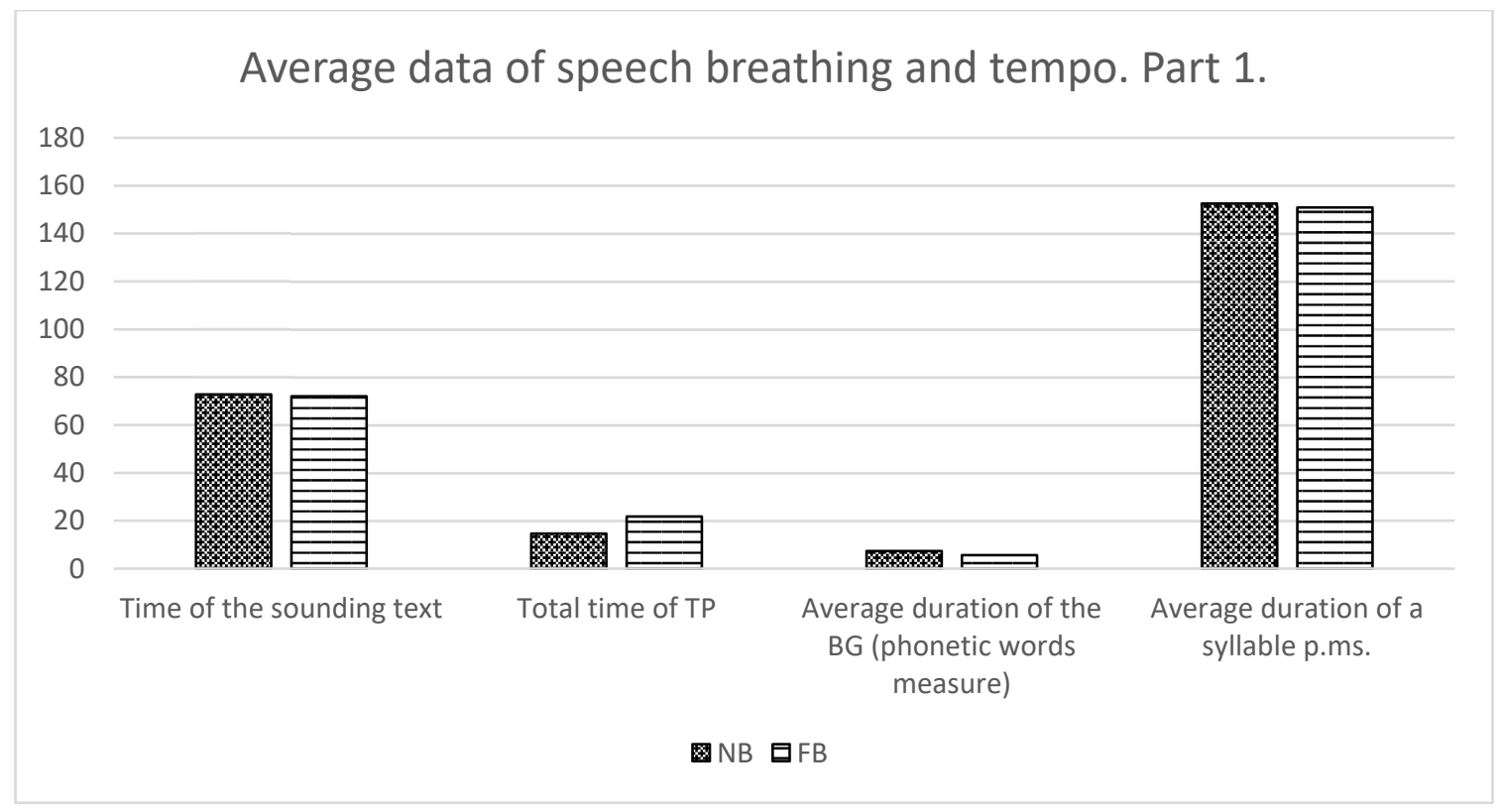

Figure 3: General characteristics of speech breathing and the tempo of reading of the experimental text by different participants during NB and FB

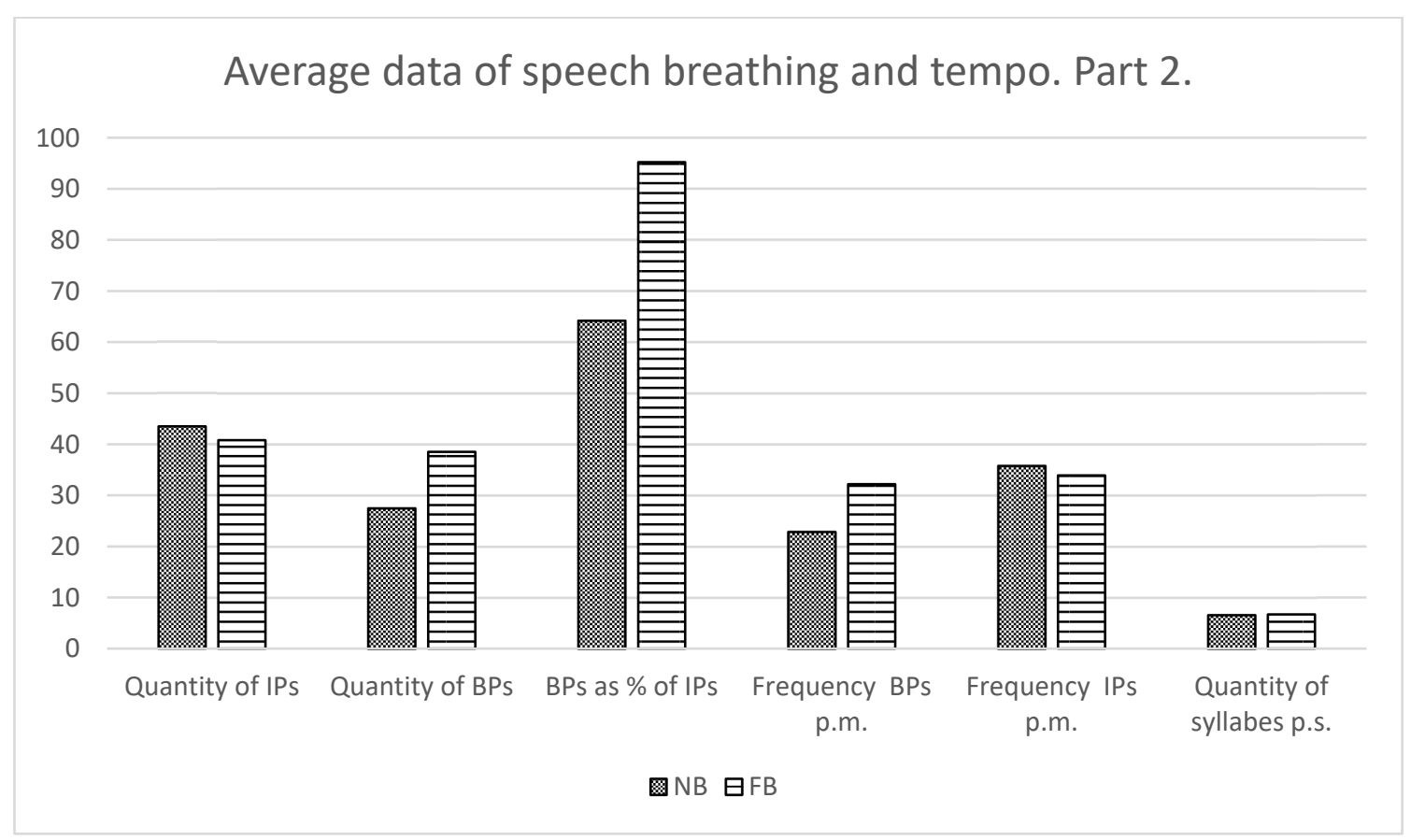

Figure 4: General characteristics of speech breathing and the tempo of reading of the experimental text by different participants during NB and FB

As seen from Table 2 and Figures 3 and 4, the differences in FB are more related to the quantity of BPs than to the tempo and the time of reading the text.

The type of breathing does not affect the total time of reading (the average value is 72.8 seconds during NB and 72.0 seconds during FB) and the tempo of pronouncing (the average duration of a syllable is $153 \mathrm{~ms}$ during NB and $151 \mathrm{~ms}$ during FB). During FB, the time of TPs increases by 1.5 times. It can be connected with an increase in the depth and, accordingly, the duration of inspiration. The duration of 
the breathing groups ${ }^{2}$ (BGs) decreases during FB by 1.3 times due to the fact that the participant is forced to pronounce fewer words between the BPs because their quantity and frequency increase (by 1.4 times). Therefore, during FB, BPs take up most of the IPs. The percentage of BPs from the total number of pauses during FB is 1.5 times higher than during NB. The average number of IPs is slightly decreasing in FB (from 44 to 41), as well as the frequency of their implementation per minute (from 36 to 34). This is due to the fact that the participant stops implementing TPs where they are intended, if he does not need to inhale.

Thus, the type of breathing primarily affects the number of BPs during the reading of the text. In FB, BPs take up $95 \%$ of the total number of TPs, which also increases compared to NB.

\subsection{Correlations between the localizations of BPs and the boundaries of text units in NB and FB}

The question of the correlation between the localization of BPs and the boundaries of text units in NB and FB was investigated by Krivnova [8], [9]. She found out that all the participants she interviewed avoided taking inspirations inside the clause, but certainly made inhales after completing the paragraphs, regardless of their length and complexity. A similar pattern was observed at the boundaries of sentences, and at the boundaries of clauses the number of BPs decreased. This suggested that the number and localization of BPs are determined by the intonation pausing strategy, and it is the speaker who sets this strategy: "Important parameters for the implementation of the breath at the interclausal boundaries within the sentence are the longer length of the pronounced clause, its autosemanticity and the expectation (prediction) of the expanded sentence" [8].

In the present study, the task was to determine whether speakers followed the intonation pausing strategy during FB. The data obtained is shown in Table 3 in the Appendix 5 and in Figures 5 and 6 below.

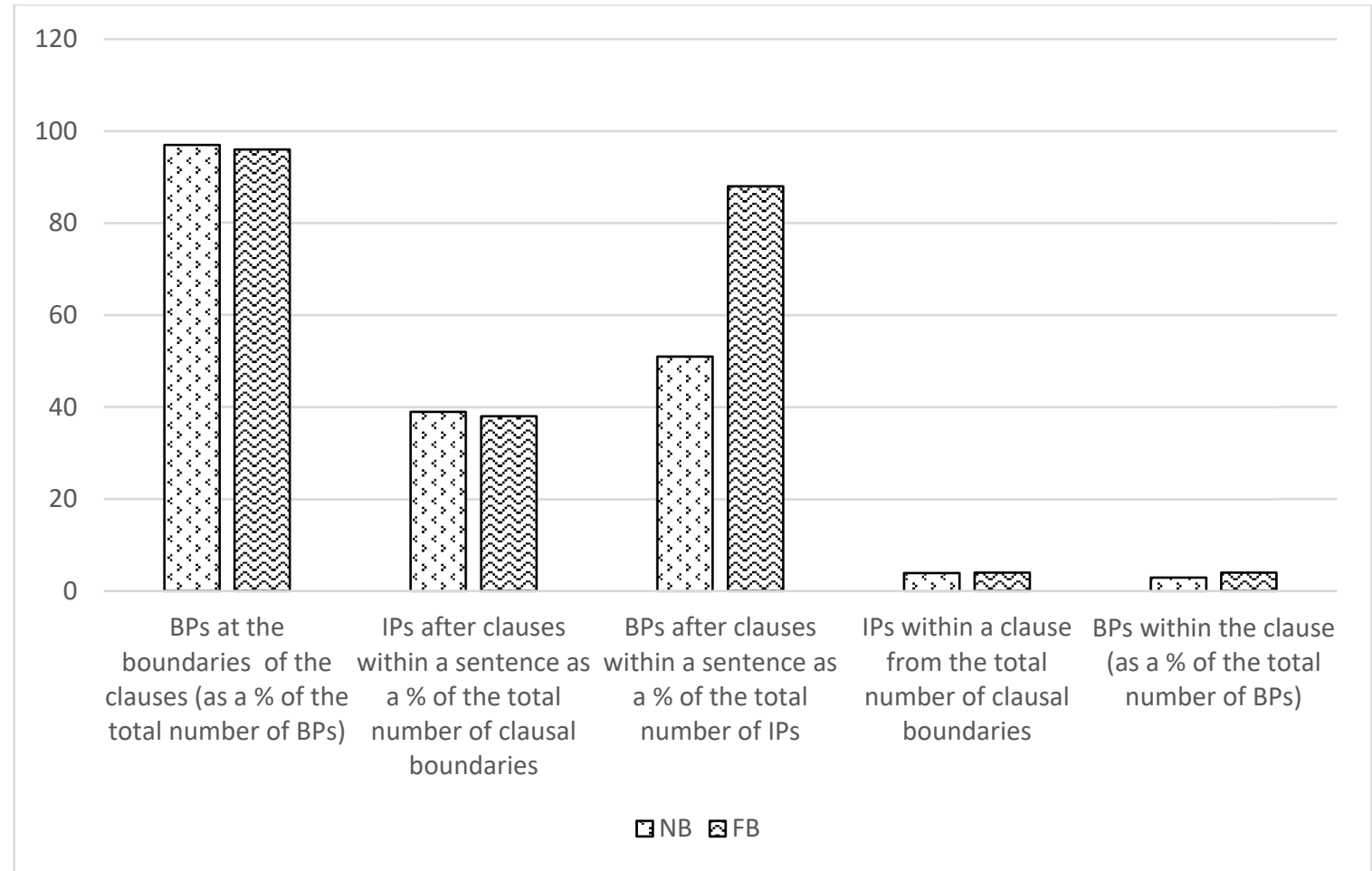

Figure 5: BPs at the boundaries of text fragments with different indexes of syntax boundary strength during NB and FB (part 1)

\footnotetext{
${ }^{2}$ Breathing group is a chain of words uttered by the speaker during one exhalation [11].
} 


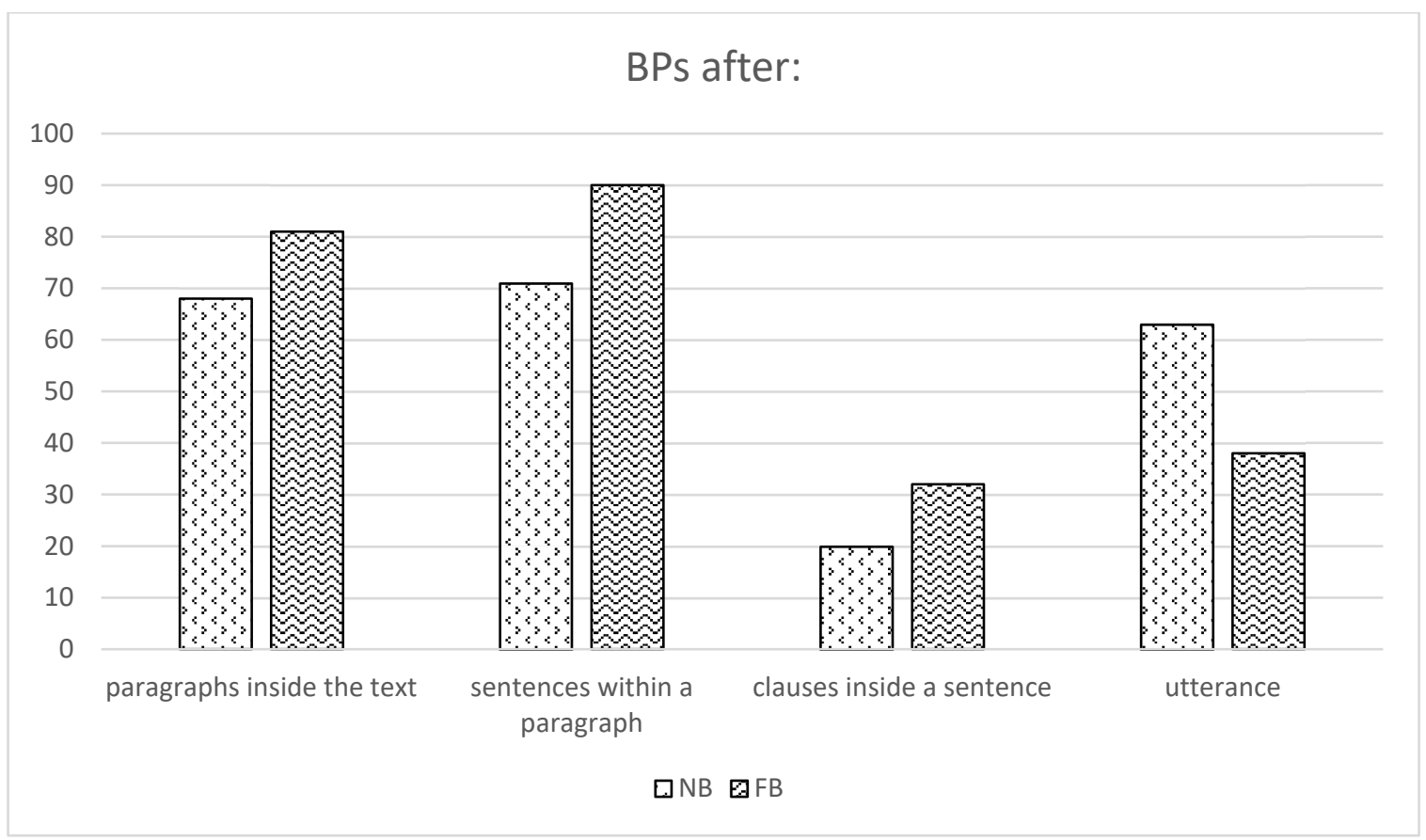

Figure 6: BPs at the boundaries of the text fragments with different indexes of syntax boundary strength during NB and FB (part 2)

As can be seen from the above data, most often the BPs coincide with the boundaries of the clausal boundaries, both in NB (97\%) and in FB (96\%). After the clauses within the sentence, in NB, the BPs take up about half of the IPs. During FB, this indicator increases by 1.7 times. The participant tries to use any pause for the realization of the inspiration. An increase in the quantity of BPs during FB is observed at all levels of text units. The fewest number of intonation pauses is found inside the clauses, both in NB $(20 \%)$ and in FB (32\%). At the same time, the number of IPs increases during FB by $12 \%$. BPs after paragraphs make up only $68 \%$ of the total number of the paragraphs. This discrepancy with the data described by Krivnova [10] can be explained by the fact that the text contains a lot of dialogic utterances, which are graphic paragraphs, but not phonetic. Nevertheless, in FB, the percentage of BPs after paragraphs increases. Breathing pauses after utterance during NB $(63 \%)$ also converges in percentage terms with the indicators of BPs after a paragraph $(68 \%)$ and a sentence $(71 \%)$. However, in FB, BPs after utterance are noted less often (38\%) than in NB; however, this cannot be considered a regular process, since this utterance is perceived by participants in different ways: either as a sentence or as part of it.

Based on what was said above, we can conclude that IPs are often used for inhales, this indicator increases during FB. The organization of speech breathing reflects the hierarchical structure of text units, regardless of the depth and frequency of breathing.

\subsection{The duration of IPs with different text localization}

The assumption that the duration of intonation pauses reflects the hierarchical structure of the text has been expressed by various linguists (Grogean/Coxtins 1979 [3]; Krivnova 2016 [11]). Krivnova conducted a number of experiments confirming this point of view [12].

At this stage of the study, the task was to calculate the average duration of BPs and NBPs in different text localizations during the readings of the same text by different participants in NB and FB and to determine whether the duration of the pause depends on its localization during FB.

The data obtained is shown in Figure 7 below. 


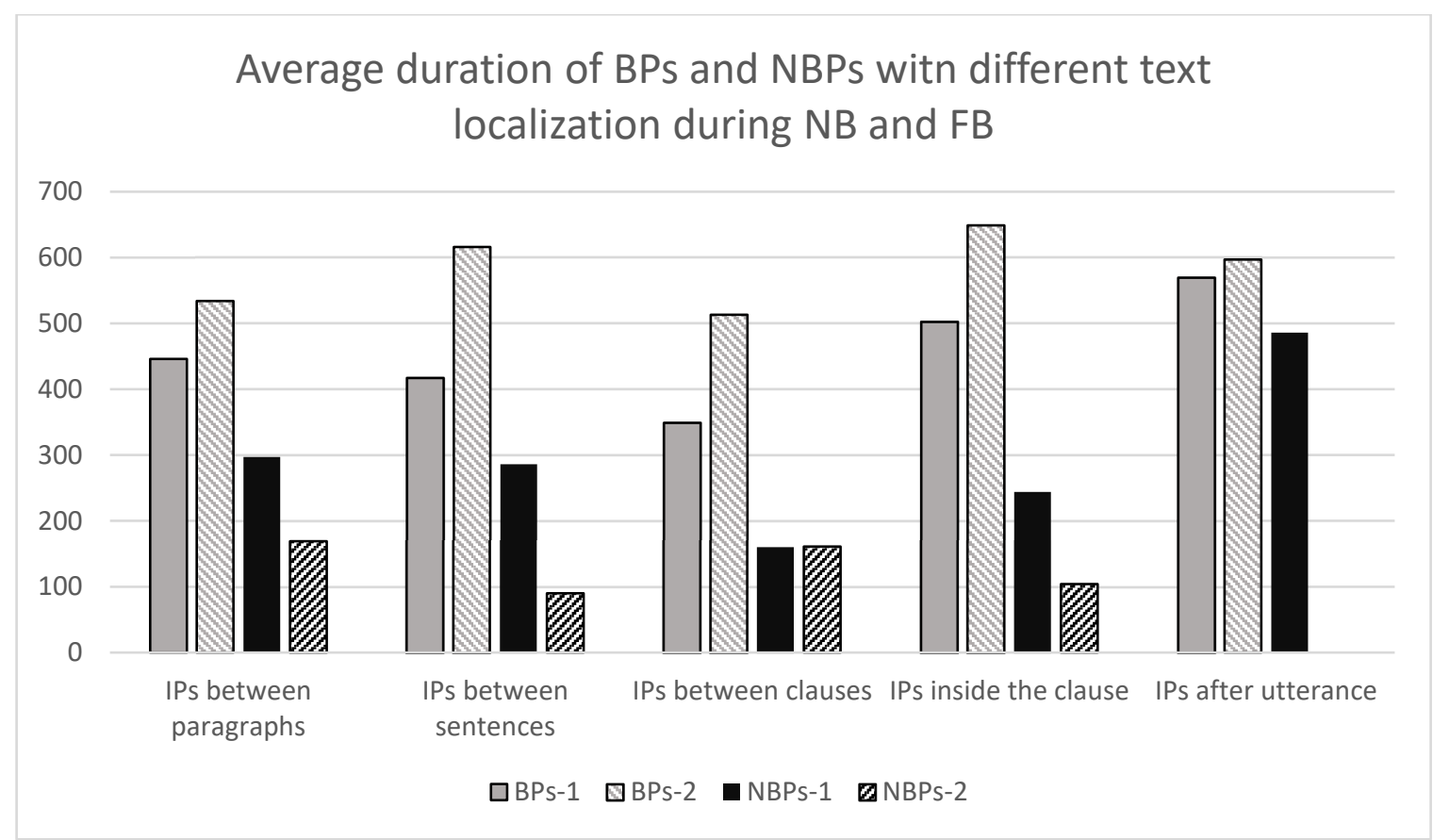

Figure 7: Average duration of BPs and IPs with different text localization during NB and FB. BPs-1 - BPs during NB. BPs-2 - BPs during FB, NBPs-1 - NBPs during NB. NBPs-2 - NBPs during FB. The duration of the pauses was determined in $\mathrm{ms}$

Detailed data on the duration of different types of pauses is provided in Table 4 in the Appendix 6.

Analyzing the results of the obtained data, we can conclude that the BP has a longer duration (1.4 times) than the NBPs, regardless of the text localization and type of breathing. In NB: the duration of the IPs reflects the hierarchical structure of the text within the concepts of paragraph $>$ sentence $>$ clause; the IP after the utterance is equal in duration to the IP after the sentence; the IP inside the clause is forced or interpreted as a pause between other text units. The duration of IPs during FB does not reflect the hierarchical structure of the text. The duration of the BPs in FB is longer than in NB, the duration of the NBPs, on the contrary, in FB is less than in normal breathing, except for the NBPs between clauses, where their duration is equal. The average duration of IPs during FB increases by 1.38 times compared to NB (see Table 2).

The study thus shows that the duration of the pause depends on the presence of inspiration in it and the type of breathing. The BP is always longer than the NBP. The duration of the BP during FB increases, and the duration of the NBP decreases.

\section{Conclusions}

The obtained results confirm that the type of breathing affects the organization of the rhythmic-intonational segmentation of the text. During both normal and forced breathing, the participants tend to pause at the boundaries of text units. However, during forced breathing, not all potential intonation pauses are realized, but only those that are necessary for the realization of inspiration.

The type of breathing most depends on the quantity of breathing pauses that are implemented during the reading of the text. During forced breathing, breathing pauses take up 95\% of the total number of temporal intonation pauses - this is $31 \%$ more than during normal breathing.

In normal breathing, the duration of the intonation pause depends on its localization and most often shows the hierarchical segmentation of the text: paragraph $(446 \mathrm{~ms})>$ sentence $(417 \mathrm{~ms})>$ clause $(349$ $\mathrm{ms})$. In forced breathing, this pattern is not observed. The duration of the pause does not depend on the location of its implementation. 


\section{References}

[1] Bol'shev A.S., Sidorov D.G., Ovchinnikov S.A. (2017), Heart rate. Physiological and pedagogical aspects [Chastota serdechnyh sokrashchenij. Fiziologo-pedagogicheskie aspekty], NNGASU, Nizhny Novgorod.

[2] Dubrovskiy V.I. (2002), Sports Medicine [Sportivnaya medicina], VLADOS, Moscow.

[3] Grosjean F., Collins M. (1979), Breathing, Pausing and Reading, Phonetica 36, Boston, pp. 98 - 114.

[4] Kayumova A.F. (2016), Physiology of the respiratory system: a textbook [Fiziologiya sistemy dyhaniya: uchebnoe posobie], FSBEI HE BSMU of the Ministry of Health of Russia [FBGOU VO BGMU Minzdrava Rossii], Ufa.

[5] Knyazev S.V., Pozharickaya S.K. (2012), Modern Russian literary language: Phonetics, orthoepy, graphics and orthography [Sovremennyj russkij literaturnyj yazyk: Fonetika, orfoepiya, grafika i orfografiya], Academic Project [Akademicheskij proekt], Gaudeamus, Moscow.

[6] Kodzasov S.V., Krivnova O.F. (2001), General phonetics [Obshchaya fonetika], RSUH [RGGU], Moscow.

[7] Krivnova O.F., Chardin I.S. (1999), Pausing in automatic speech synthesis [Pauzirovanie pri avtomaticheskom sinteze rechi], Theory and practice of speech research (APCO-99) [Teoriya i praktika rechevyh issledovanij (APCO-99)], Moscow, pp. 87-103.

[8] Krivnova O.F. (2007), Factor of speech respiration in intonational-pausal articulation of speech [Faktor rechevogo dyhaniya $\mathrm{v}$ intonacionno-pauzal'nom chlenenii rechi], Linguistic polyphony [Lingvisticheskaya polifoniya], Languages of Slavic cultures [Yazyki slavyanskih kul'tur], Moscow, pp. $424-444$.

[9] Krivnova O.F. (2009), The general phonetic picture of respiratory pauses in the reproduced speech (on the reading material) [Obshchaya foneticheskaya kartina dyhatel'nyh pauz $\mathrm{v}$ reproducirovannoj rechi (na materiale chteniya)], Phonetics and Grammar: present, past, future [Fonetika i grammatika: nastoyashchee, proshedshee, budushchee], Vol. 11, pp. 61-71.

[10] Krivnova O.F. (2010), Duration of respiratory pauses with different text localization [Dlitel'nost' dyhatel'nyh pauz s raznoj tekstovoj lokalizaciej], Phonetics today: Materials of reports and messages of the VI International Scientific Conference [Fonetika segodnya: Materialy dokladov i soobshchenij VI Mezhdunarodnoj nauchnoj konferencii], Moscow, pp. 84-86.

[11] Krivnova O.F. (2016), Prosodic phrasing in spoken text: localization of breathing pauses [Prosodicheskoe chlenenie zvuchashchego teksta: tekstovaya lokalizaciya dyhatel'nyh pauz], Computational Linguistics and Intellectual Technologies: Proceedings of the International Conference "Dialog 2016" [Komp'yuternaya lingvistika i intellektual'nye tekhnologii: Po materialam mezhdunarodnoj ezhegodnoj konferencii «Dialogue 2016»], Moscow, pp. 340-354.

[12] Krivnova O.F. (2017), Phonetic characteristics of breathing pauses with dIfferent text localization [Foneticheskie harakteristiki dyhatel'nyh pauz s raznoj tekstovoj lokalizaciej], Computational Linguistics and Intellectual Technologies: Proceedings of the International Conference "Dialog 2017" [Komp'yuternaya lingvistika i intellektual'nye tekhnologii: Po materialam mezhdunarodnoj ezhegodnoj konferencii «Dialogue 2017»], Moscow, pp. 207-220.

[13] Sanderman A.A. (1996), Prosodic phrasing: production, perception, acceptability and comprehension, Thesis Technische Universiteit Eindhoven, Eindhoven.

[14] Testelets Ya.G. (2001), Introduction to the general syntax [Vvedenie v obshchij sintaksis], Russian State University for the Humanities [Rossijskij gosudarstvennyj gumanitarnyj universitet], Moscow.

[15] Zarifyan A.G. (2013), Physiology of respiration: a textbook [Fiziologiya dyhaniya: uchebnoe posobie], KRSU, Bishkek.

[16] Zellner B. (1994), Pauses and the temporal structure of speech, Fundamentals of speech synthesis and speech recognition, Chichester, pp. $41-62$.

[17] Zinder L.R. (1979), General phonetics: Textbook. Manual [Obshchaya fonetika: Ucheb. Posobie], Higher School [Vysshaya shkola], Moscow. 


\section{Appendix}

Appendix 1. In Table 1, column 1 shows the text units of different strength, taking into account their hierarchical boundaries. In column 2 (without the parentheses) the number of units of hierarchical boundary that are not final unit in a boundary of higher strength is indicated, and in parentheses - the number of units that complete a higher-strength boundary text unit. The data is presented in Table 1.

\begin{tabular}{|c|c|c|c|c|}
\hline Text units & $\begin{array}{l}\text { Quantity in the } \\
\text { text }\end{array}$ & $\begin{array}{l}\text { Quantity of text } \\
\text { units in lower } \\
\text { strength units }\end{array}$ & $\begin{array}{l}\text { Quantity in pho- } \\
\text { netic words }\end{array}$ & $\begin{array}{l}\text { End punctua- } \\
\text { tion mark }\end{array}$ \\
\hline \multirow[t]{2}{*}{ Paragraph } & \multirow[t]{2}{*}{7} & from 1 to 10 & from 2 to 84 & \multirow[t]{2}{*}{.$? !$} \\
\hline & & Avg. 3,8 & Avg. 28,6 & \\
\hline \multirow{2}{*}{$\begin{array}{l}\text { Sentence inside a } \\
\text { paragraph }\end{array}$} & \multirow{2}{*}{$\begin{array}{l}22(+5)-\text { end- } \\
\text { points in a } \\
\text { higher strength } \\
\text { unit }\end{array}$} & & from 2 to 14 & \multirow[t]{2}{*}{.$? !$} \\
\hline & & Avg. 2,5 & Avg. 7,4 & \\
\hline \multirow{2}{*}{$\begin{array}{l}\text { Clause inside the } \\
\text { sentence }\end{array}$} & \multirow[t]{2}{*}{$41(+27)$} & \multirow[t]{2}{*}{-} & from 1 to 7 & \multirow[t]{2}{*}{$.,-? !:$} \\
\hline & & & Avg. 2,9 & \\
\hline Utterance $Э x$ & 1 & - & 1 & \\
\hline
\end{tabular}

Table 1: Compositional and syntactic structure of the experimental text

\section{Appendix 2}

Experimental text with the distribution of pauses in accordance with the reading of Participant e-1 (during NB). The paragraph is separated by an interval, / is the sentence boundary inside the paragraph, ** is the clause boundary inside the sentence, the utterance is italicized. The pause duration in seconds is indicated in parentheses. After the parentheses there is the character of the pause (BP or NBP). The length of the syntagma in seconds is given as superscript:

Кеша всегда приходил в сапогах ${ }^{1.680235} /(0.298)$ NBP - любил их, видно. ${ }^{0.811328} / * *(0.455391)$ ВР Никогда не разувался: ${ }^{1.177735} /(0.177969)$ ВР в сапогах руки мыл, ${ }^{1.151563} /(0.173)$ ВР ел, ${ }^{0.355938} /$ (0.113) NBP пил, / спать ложился. ${ }^{1.230078 / * * ~(0.392578) ~ В Р ~ О д н а ж д ы ~ К е ш а ~ п р о п а л . ~}{ }^{1.188203}$ /** (0.389961) ВР Три дня его дома не было, ${ }^{1.350469} /(0.123)$ NBP отец с матерью обыскались. ${ }^{1.463008} /$ ** (0.259102) BP На четвертый - пришел, ${ }^{1.206524}$ / (0.102070) NBP и как пришел-то ${ }^{0.902930 ~ / ~}$ (0.264336) ВР - босиком! $!^{0.591484} / * *(0.358555)$ ВР Рубашка вся помята, ${ }^{1.358321} /(0.253867)$ ВР у куртки пуговицы оторваны, / стоит, / переминается. ${ }^{2.648594}$ / ** (0.269570) NBP Ну, отец его давай расспрашивать. ${ }^{1.583399} / * *(0.410899)$ ВР А Кеша только зубами стучит. ${ }^{1.570313} / * *(0.298359)$ ВР Папа допытывается: ${ }^{0.926485} /$ (0.303594) NBP «Колись, зараза, / где тебя носило?!» ${ }^{1.845118}$ - / ВР (0.259102) а по радио поэт Левитанский читает «Как показать зиму». $2.973126 / * *(0.562695)$ ВР Да вот же лучшая иллюстрация / - замерзший и растерянный блудный Кеша! $!^{3.690235}$ / ** (0.429219) ВР «Слушай, / - говорю я еле увел. ${ }^{0.722344} / * *(0.262)$ ВР Сидит Кеша над тазиком, / щеки трет: ${ }^{2.072813} /(0.408281)$ ВР

- Пошел в кафе, / - говорит ${ }^{1.240547}$ / (0.246) ВР- - хотел спокойно посидеть, ${ }^{1.455157}$ / (0.177969) ВР заказать что-нибудь. ${ }^{1.073047} / * *(0.337617)$ Заказать заказал, ${ }^{1.002383} /(0.102070)$ а в рот ни куска не попало ${ }^{1.436836} /(0.222461) \mathrm{BP}$ - это все Пашка, гад: ${ }^{1.096602} /(0.264336) \mathrm{BP}$ «Сыграй кружочек!» / (0.183203) - ага, сыграл! $!^{0.926485} / * *(0.476328)$ NBP

Я ему говорю: $:^{0.680469} /(0.319297)$ ВР «Так ты что, / в карты что ли сапоги продул?» 2.114688 / ** $(0.350703)$ NBP 
Продул. ${ }^{0.554844} / * *(0.144)$ NBP Еще как продул. ${ }^{1.436836} / * *(0.337617)$ ВР Он же не только сапоги, / он и получку просадил, за два месяца. ${ }^{3.030704} / * *(0.471094)$ ВР Эx. ${ }^{0.366406}(0.565313)$ ВР Тут Кеша как начнет слезы утирать. ${ }^{1.805860} / * *(0.209375)$ NBP А мне его жалко страшно, дурня этакого! $!^{2.093750} / * *(0.423984)$ ВР Он человек-то хороший. ${ }^{1.141094} / * *(0.272)$ ВР Знаете как он папе с мамой помог, / когда им квартиру не давали? $?^{2.931251}$ / ** (0.330) ВР Это ведь он бегал, / все бумажки собирал, / письма писал. ${ }^{2.653829}$ / ** (0.403047) ВР А как он со мной нянчился, ${ }^{1.397578} /$ (0.690938 сглатывание) NBP когда мама заболела. ${ }^{1.224844} / * *(0.408281)$ ВР Однажды ночью разбудил меня и шепчет: ${ }^{2.088516} /(0.413516)$ ВР

- Давай просыпайся, / тут такое! ${ }^{1.863438}$ / ** $(0.465859)$ NBP

- Что случилось? $?^{0.884610} / * *(0.188438)$ NBP

- Показать хочу! $!^{0.916016} /(0.264336)$ ВР - и протягивает мне какой-то странный сверток, ${ }^{2.046641}$ (0.196289) ВР тяжелый и теплый. ${ }^{1.012852}$ / ** (0.389961) ВР Это дядя Кеша ежика во дворе нашел ${ }^{1.965508} /(0.256484)$ ВР и в полотенце его завернул, ${ }^{1.394961} /(0.177969)$ ВР чтобы я посмотрел. ${ }^{1.023321} / * *(0.434453)$ ВР

Experimental text with the distribution of pauses in accordance with the reading of Participant e-2 (during FB). The paragraph is separated by an interval, / is the sentence boundary inside the paragraph, ** is the clause boundary inside the sentence, the utterance is italicized. The pause duration in seconds is indicated in parentheses. After the parentheses there is the character of the pause (BP or NBP). The length of the syntagma in seconds is given as superscript:

Кеша всегда приходил в сапогах ${ }^{1.509348} /(0.450671)$ ВР - любил их, видно. / ** Никогда не разувал(ся): ${ }^{2.024020} /(0.448004)$ ВР в сапогах руки мыл, / ел, / пил, ${ }^{1.717350} /(0.597339)$ ВР спать ложил(ся). / ** Однажды Кеша пропал. ${ }^{2.048020} /$ ** (0.605339) ВР Три дня его дома не было $0.636007 /(0.552005)$ ВР отец с матерью обыскались. / ** На четвертый - при(шел), ${ }^{2.704026} /(0.384004)$ ВР и как пришелто / - босиком! 1.434680 / ** (0.626673) ВР Рубашка вся помята, ${ }^{1.194678} /(1.317346)$ ВР у куртки пуговицы оторваны, ${ }^{1.610682} /(0.437338)$ ВР стоит, / переминается. ${ }^{1.184011} /$ ** $(0.637339)$ ВР Ну, отец его давай расспрашивать. ${ }^{1.573348} / * *(0.546672)$ ВР А Кеша ${ }^{0.538672}(0.224002)$ ВР только зубами стучит. ${ }^{1.040010} / * *(0.509338)$ ВР Папа допытывается: $: .944009$ / (0.474671) ВР «Колись, зараза, / где тебя носило?!» ${ }^{1.725350} /(0.525338)$ ВР - а по радио поэт Левитанский читает «Как показать зиму». ${ }^{2.981362}$ / ** (0.522672) ВР Да вот же лучшая иллюстрация - / замерзший и растерянный блудный Кеша! $!^{3.258698} / * *(0.432004)$ ВР «Слушай, / - говорю (я) ${ }^{0.874675} /(0.418671)$ ВР - пойдем, / ну, пойдем, / умоешься» 1.533348 / (0.208002) ВР - еле увел. 0 ,624006 / ** (0.464004) ВР Сидит Кеша над тазиком, / щеки трет: ${ }^{1.989353} /(0.402671)$ ВР

- Пошел в кафе, / - говорит ${ }^{1.224012}$ / (0.336003) ВР - хотел спокойно посидеть, / заказать чтони(будь). ${ }^{2.368023} / * *(0.312003)$ ВР Заказать заказал, / а в рот ни куска не попало ${ }^{2.421357} /(0.448004)$ ВР - это все Пашка, гад: ${ }^{1.120011} /$ (0.341337) ВР «Сыграй кружочек!» / - ага, сыграл! $!^{1.858685} /$ ** $(0.528005) \mathrm{BP}$

Я ему говорю: $:^{0.618673} /(0.469338)$ ВР «Так ты что, / в карты что ли сапоги продул?» 1.821357 / ** $(0.461338) \mathrm{BP}$

Продул. / ** Еще как продул. ${ }^{1.298679} /$ ** (0.474671) ВР Он же не только сапоги, ${ }^{1.056010} /(0.394670)$ ВР он и получку просадил, за два месяца. ${ }^{1.968019} / * *(0.490671)$ ВР Эx. ${ }^{0.453338}(0.389337)$ ВР Тут Кеша как начнет слезы утирать. ${ }^{1.925352} / * *(0.922676)$ - ВР А мне его жалко страшно, ${ }^{1.210678}$ (0.458671) ВР дурня этакого! $!^{0.752007} / * *(0.554672)$ ВР Он человек-то хороший. ${ }^{1.077344} / * *$ (0.538672) ВР Знаете как он папе с мамой помог, / когда им квартиру не давали? ${ }^{3.322699}$ / ** (0.378670) ВР Это ведь он бегал, / все бумажки собирал, / письма писал. ${ }^{2.730693} / * *(0.320003)$ ВР А как он со мной нянчился, / когда мама заболела. ${ }^{2.506691} / * *(0.373337)$ ВР Однажды ночью разбудил меня и шепчет: ${ }^{1.994686} /(0.490671)$ ВР 
- Давай просыпайся, / тут такое! $!^{1733350 / * *}(0.389337)$ ВР

- Что случилось $?^{0.714674} / * *(0.266669) \mathrm{BP}$

- Показать хочу! $!^{0.789341} /(0.224002)$ ВР - и протягивает мне какой-то странный сверток, ${ }^{1.786684}$ (0.346670) ВР тяжелый и теплый. $.^{.930676} / * *(0.642673)$ ВР Это дядя Кеша ежика во дворе нашел ${ }^{2.002686} /(0.362670)$ ВР и в полотенце его завернул, / чтобы я посмотрел. ${ }^{2.213355} / * *(0.410671)$ BP

\section{Appendix 3}

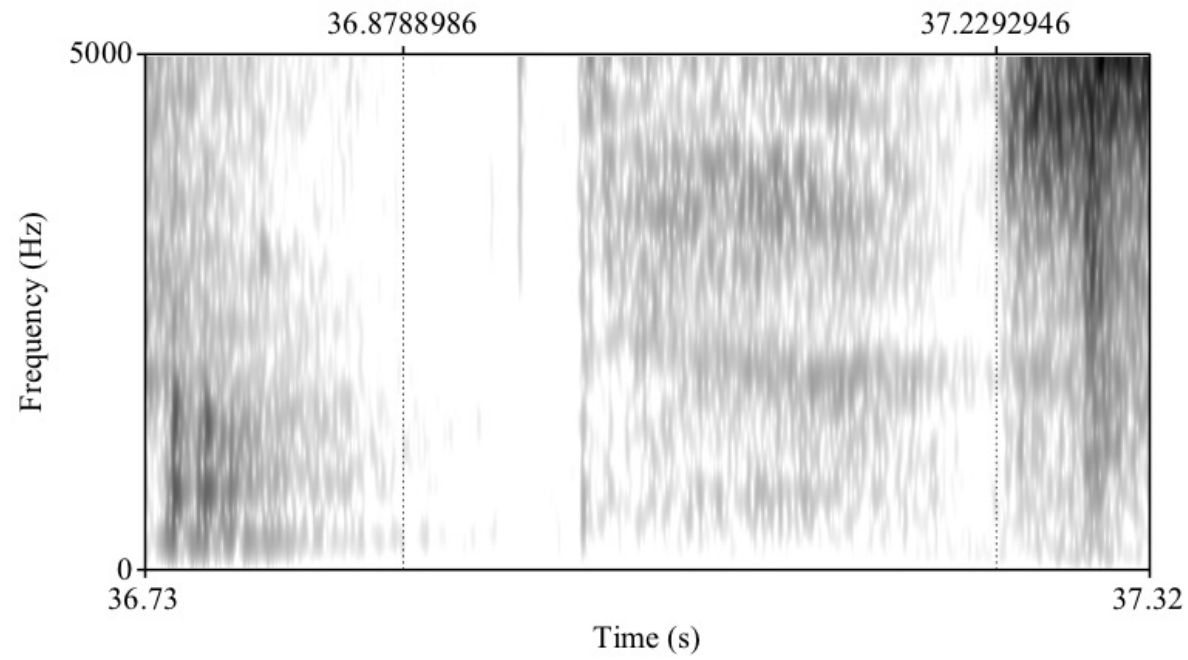

Figure 1-a: Dynamic spectrogram of the BP after the sentence during NB

In Figure 1-a, the cursors highlight the BP after the sentence during NB. The pause is located between the sounds [ə] and [s]. The duration of the segmented fragment was $350 \mathrm{~ms}$ in this case.

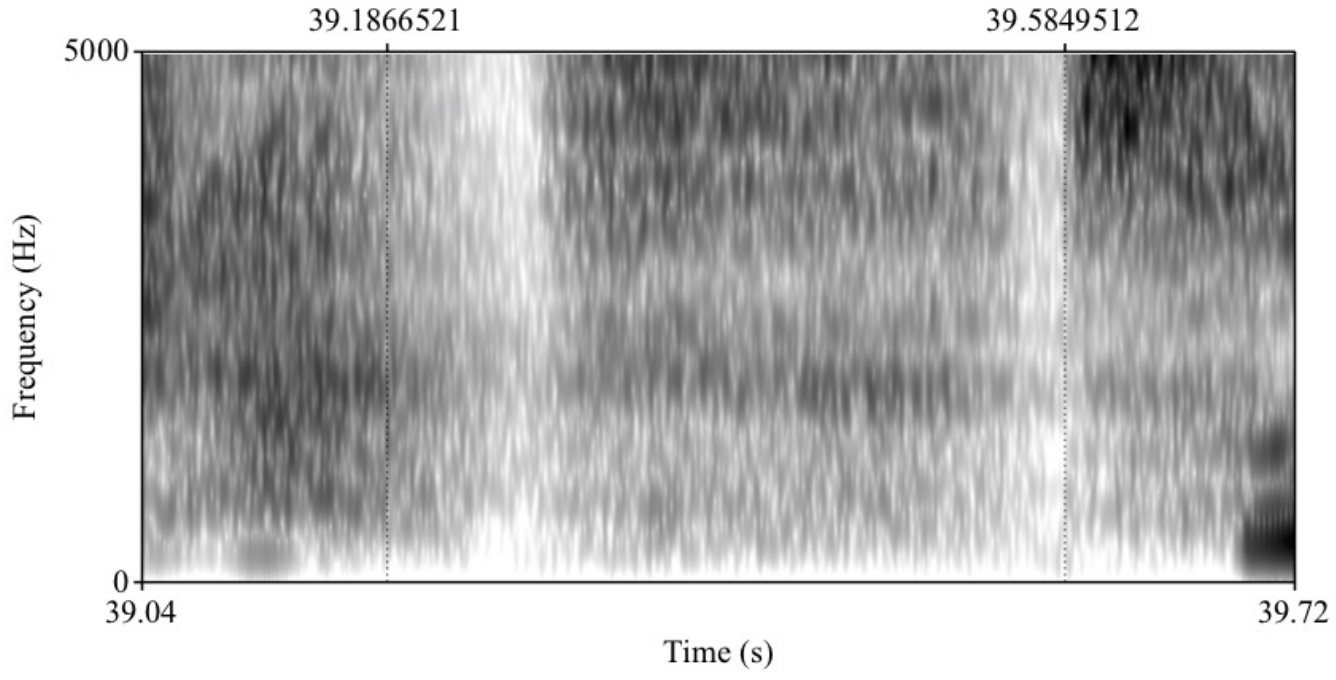

Figure 2-a: Dynamic spectrogram of the BP after the sentence during FB

In Figure 2-a, the cursors highlight the BP after the sentence during FB. The pause is located between the sounds [ə] and [s]. The duration of the segmented fragment was $398 \mathrm{~ms}$ in this case. 


\section{Appendix 4}

\begin{tabular}{|c|c|c|c|c|c|c|c|c|c|c|c|}
\hline \multirow{2}{*}{ 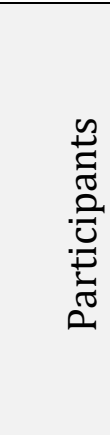 } & \multirow{2}{*}{ 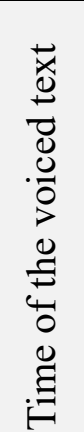 } & \multirow{2}{*}{ 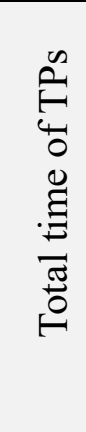 } & \multirow{2}{*}{ 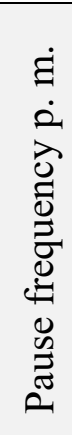 } & \multirow[t]{2}{*}{ IPs } & \multirow{2}{*}{$\begin{array}{l}\text { BPs } \\
\text { as a } \\
\% \text { of } \\
\text { IPs }\end{array}$} & \multirow{2}{*}{ 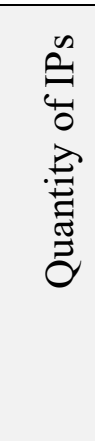 } & \multicolumn{2}{|c|}{$\begin{array}{l}\text { The length of } \\
\text { the BG in pho- } \\
\text { netic words }\end{array}$} & \multirow{2}{*}{ 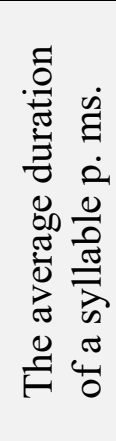 } & \multirow{2}{*}{ 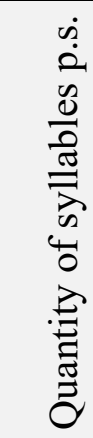 } & \multirow{2}{*}{ 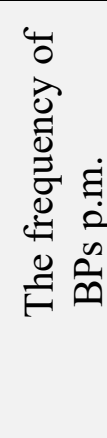 } \\
\hline & & & & & & & $\sum_{2}^{\infty 0}$ & 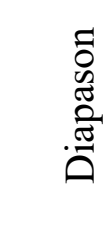 & & & \\
\hline a-1 & 76.1 & 17,1 & 37,5 & 47 & 57,5 & 27 & 7,4 & $2-12$ & 159 & 6,3 & 21,4 \\
\hline$a-2$ & 75,8 & 23,3 & 40 & 52 & 88,5 & 46 & 4,3 & $2-9$ & 159 & 6,3 & 37,5 \\
\hline b-1 & 69,8 & 11,7 & 33,3 & 38 & 60,5 & 23 & 8,7 & $1-16$ & 147 & 6,8 & 20 \\
\hline b-2 & 67 & 15,7 & 21,4 & 24 & 100 & 24 & 8,7 & $3-18$ & 142 & 7,1 & 21,4 \\
\hline c-1 & 65,1 & 16,1 & 42,9 & 48 & 54,2 & 26 & 7,6 & $2-16$ & 137 & 7,3 & 24 \\
\hline$c-2$ & 64,2 & 21,1 & 37,5 & 40 & 100 & 40 & 5 & $2-12$ & 135 & 7,4 & 37,5 \\
\hline d-1 & 76,8 & 12,4 & 31,6 & 40 & 47,5 & 19 & 10,4 & $5-21$ & 161 & 6,2 & 15 \\
\hline d-2 & 76,2 & 26,6 & 27,3 & 34 & 94,1 & 32 & 6,25 & $2-13$ & 159 & 6,3 & 25 \\
\hline e-1 & 78,4 & 16,7 & 40 & 54 & 68,5 & 37 & 5,4 & $1-12$ & 164 & 6,1 & 28,6 \\
\hline e-2 & 76 & 22,1 & 37,5 & 47 & 100 & 47 & 4,2 & $1-10$ & 159 & 6,3 & 37,5 \\
\hline$f-1$ & 74,9 & 17,5 & 31,6 & 40 & 77,5 & 31 & 6,5 & $1-12$ & 156 & 6,4 & 25 \\
\hline$f-2$ & 72,7 & 22,8 & 33,3 & 40 & 92,5 & 37 & 5,4 & $1-12$ & 153 & 6,6 & 30 \\
\hline g-1 & 78 & 15,3 & 37,5 & 48 & 56,3 & 27 & 7,4 & $1-16$ & 164 & 6,1 & 20,7 \\
\hline g-2 & 77,5 & 20,8 & 40 & 52 & 86,5 & 45 & 4,4 & $1-12$ & 161 & 6,2 & 35,3 \\
\hline h-1 & 63 & 11,4 & 31,6 & 33 & 90,9 & 30 & 6,6 & $2-12$ & 132 & 7,6 & 28,6 \\
\hline h-2 & 66,8 & 22 & 33,3 & 37 & 100 & 37 & 5,4 & $1-12$ & 139 & 7,2 & 33,3 \\
\hline Avg.-1 & 72,8 & 14,8 & 35,8 & 43,5 & 64,1 & 27,5 & 7,5 & $\begin{array}{l}1,9- \\
14,6\end{array}$ & 152,5 & 6,6 & 22,9 \\
\hline Avg.-2 & 72 & 21,8 & 33,9 & 40,8 & 95,2 & 38,5 & 5,6 & $\begin{array}{l}1,6- \\
12,3\end{array}$ & 150,9 & 6,7 & 32,2 \\
\hline
\end{tabular}

Table 2: General characteristics of speech breathing and the tempo of reading the experimental text by different participants during NB and FB 


\section{Appendix 5}

\begin{tabular}{|c|c|c|c|c|c|c|c|c|c|}
\hline \multirow{2}{*}{ 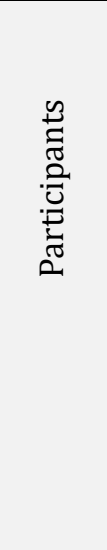 } & \multirow{2}{*}{ 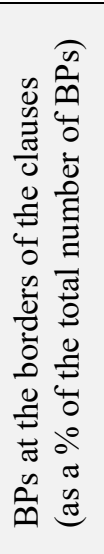 } & \multicolumn{4}{|c|}{$\begin{array}{l}\text { BPs after text units of different } \\
\text { syntax strength (as a } \% \text { of the } \\
\text { total number of units of the cor- } \\
\text { responding type) }\end{array}$} & \multirow{2}{*}{ 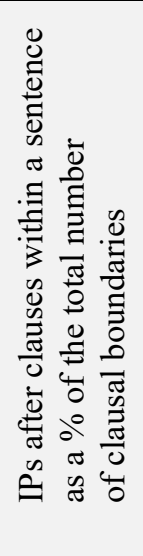 } & \multirow{2}{*}{ 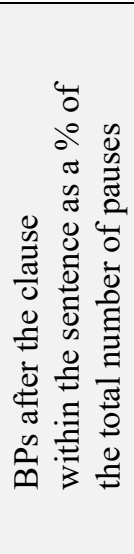 } & \multirow{2}{*}{ 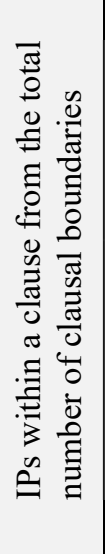 } & \multirow{2}{*}{ 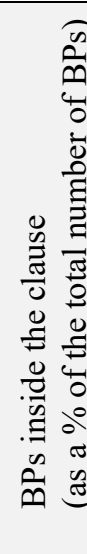 } \\
\hline & & 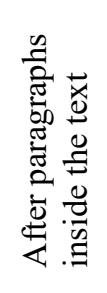 & 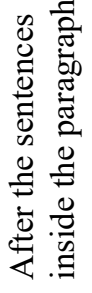 & 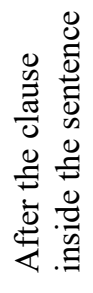 & 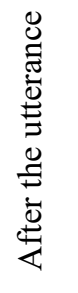 & & & & \\
\hline a-1 & 96 & 57 & 64 & 22 & 100 & 41 & 54 & 10 & 4 \\
\hline a-2 & 93 & 57 & 95 & 49 & 0 & 59 & 83 & 7 & 7 \\
\hline b-1 & 96 & 57 & 73 & 7 & 100 & 24 & 29 & 2 & 4 \\
\hline$b-2$ & 100 & 43 & 91 & 5 & 0 & 5 & 100 & 0 & 0 \\
\hline c-1 & 96 & 71 & 73 & 15 & 0 & 41 & 36 & 7 & 4 \\
\hline $\mathrm{c}-2$ & 98 & 86 & 100 & 32 & 0 & 41 & 78 & 2 & 2 \\
\hline d-1 & 100 & 71 & 50 & 12 & 0 & 29 & 41 & 5 & 0 \\
\hline$d-2$ & 97 & 86 & 77 & 22 & 0 & 27 & 81 & 2 & 3 \\
\hline e-1 & 97 & 43 & 82 & 41 & 100 & 63 & 65 & 2 & 3 \\
\hline$e-2$ & 91 & 100 & 82 & 49 & 100 & 49 & 100 & 10 & 9 \\
\hline$f-1$ & 97 & 100 & 82 & 17 & 100 & 32 & 53 & 2 & 3 \\
\hline$f-2$ & 97 & 86 & 91 & 29 & 100 & 34 & 85 & 2 & 3 \\
\hline g-1 & 96 & 57 & 68 & 22 & 100 & 54 & 41 & 2 & 4 \\
\hline $\mathrm{g}-2$ & 98 & 100 & 95 & 44 & 100 & 59 & 75 & 5 & 2 \\
\hline h-1 & 100 & 86 & 73 & 24 & 0 & 27 & 89 & 0 & 0 \\
\hline h-2 & 97 & 86 & 91 & 29 & 0 & 29 & 100 & 2 & 3 \\
\hline Avg.-1 & 97 & 68 & 71 & 20 & 63 & 39 & 51 & 4 & 3 \\
\hline Avg.-2 & 96 & 81 & 90 & 32 & 38 & 38 & 88 & 4 & 4 \\
\hline
\end{tabular}

Table 3: BPs at the boundaries of text fragments of different syntax strength during NB and FB 


\section{Appendix 6}

\begin{tabular}{|c|c|c|c|c|c|c|c|c|c|c|}
\hline \multicolumn{7}{|c|}{ IPs between } & \multirow{2}{*}{\multicolumn{2}{|c|}{$\begin{array}{l}\text { IP inside a } \\
\text { clause }\end{array}$}} & \multirow{2}{*}{\multicolumn{2}{|c|}{$\begin{array}{l}\text { IP after utter- } \\
\text { ance }\end{array}$}} \\
\hline & \multicolumn{2}{|c|}{ paragraphs } & \multicolumn{2}{|c|}{ sentences } & \multicolumn{2}{|c|}{ clauses } & & & & \\
\hline & BP & NBP & BP & NBP & BP & NBP & BP & NBP & BP & NBP \\
\hline$a-1$ & 0,524 & 0,308 & 0,486 & 0,287 & 0,401 & 0,174 & 0,457 & 0,172 & 0,605 & - \\
\hline$a-2$ & 0,528 & 0,232 & 0,538 & - & 0,451 & 0,131 & 0,317 & - & - & - \\
\hline IP & \multicolumn{2}{|c|}{$0,463 / 0,429$} & \multicolumn{2}{|c|}{$0,419 / 0,538$} & \multicolumn{2}{|c|}{$0,288 / 0,398$} & \multicolumn{2}{|c|}{$0,314 / 0,317$} & \multicolumn{2}{|l|}{$0,605 /-$} \\
\hline $\mathrm{b}-1$ & 0,321 & 0,124 & 0,436 & 0,213 & 0,303 & 0,116 & 0,501 & - & 0,501 & - \\
\hline $\mathrm{b}-2$ & 0,496 & - & 0,702 & 0,090 & 0,393 & - & - & - & - & - \\
\hline IP & \multicolumn{2}{|c|}{$0,237 / 0,496$} & \multicolumn{2}{|c|}{$0,376 / 0,673$} & \multicolumn{2}{|c|}{$0,172 / 0,393$} & \multicolumn{2}{|l|}{$0,501 /-$} & \multicolumn{2}{|l|}{$0,501 /-$} \\
\hline c-1 & 0,464 & 0,332 & 0,359 & 0,376 & 0,329 & 0,186 & 0,317 & 0,317 & - & 0,615 \\
\hline $\mathrm{c}-2$ & 0,506 & 0,197 & 0,572 & - & 0,491 & - & 0,536 & - & - & - \\
\hline$\overline{I P}$ & \multicolumn{2}{|c|}{$0,426 / 0,462$} & \multicolumn{2}{|c|}{$0,363 / 0,572$} & \multicolumn{2}{|c|}{$0,237 / 0,491$} & \multicolumn{2}{|c|}{$0,317 / 0,536$} & \multicolumn{2}{|l|}{$0,615 /-$} \\
\hline d-1 & 0,519 & 0,216 & 0,441 & 0,218 & 0,418 & 0,121 & - & 0,244 & - & 0,362 \\
\hline $\mathrm{d}-2$ & 0,490 & 0,101 & 0,896 & - & 0,818 & 0,138 & 1,240 & - & - & - \\
\hline IP & \multicolumn{2}{|c|}{$0,432 / 0,434$} & \multicolumn{2}{|c|}{$0,329 / 0,896$} & \multicolumn{2}{|c|}{$0,245 / 0,695$} & \multicolumn{2}{|c|}{$0,244 / 1,240$} & \multicolumn{2}{|l|}{$0,362 /-$} \\
\hline e-1 & 0,419 & 0,370 & 0,380 & 0,240 & 0,275 & 0,223 & 0,566 & - & 0,566 & - \\
\hline $\mathrm{e}-2$ & 0,421 & - & 0,520 & - & 0,464 & - & 0,355 & - & 0,389 & - \\
\hline IP & \multicolumn{2}{|c|}{$0,391 / 0,421$} & \multicolumn{2}{|c|}{$0,355 / 0,520$} & \multicolumn{2}{|c|}{$0,256 / 0,464$} & $0,566 / 0$ & 355 & $0,566 / 0$ & 389 \\
\hline$f-1$ & 0,481 & - & 0,490 & 0,441 & 0,405 & 0,208 & 0,805 & - & 0,805 & - \\
\hline$f-2$ & 0,681 & 0,144 & 0,623 & - & 0,539 & - & 0,822 & - & 0,822 & - \\
\hline IP & $0,481 /$ & 604 & $0,483 /$ & 623 & $0,314 /$ & 539 & $0,805 / 0$ & 822 & $0,805 / 0$ & 822 \\
\hline g-1 & 0,451 & 0,458 & 0,367 & 0,350 & 0,333 & 0,175 & 0,368 & - & 0,368 & - \\
\hline$g-2$ & 0,507 & - & 0,463 & - & 0,370 & 0,214 & 0,579 & 0,104 & 0,579 & - \\
\hline IP & $0,454 /$ & 507 & $0,362 /$ & 463 & $0,243 /$ & 331 & $0,368 / \mathrm{c}$ & 342 & $0,368 / 0$ & 579 \\
\hline h-1 & 0,387 & 0,273 & 0,376 & 0,161 & 0,329 & 0,074 & - & - & - & - \\
\hline $\mathrm{h}-2$ & 0,645 & - & 0,617 & - & 0,579 & - & 0,694 & - & - & - \\
\hline IP & $0,371 /$ & 645 & $0,364 /$ & 0,617 & $0,306 /$ & 579 & $-10,694$ & & - & \\
\hline Avg.-1 & 0,446 & 0,297 & 0,417 & 0,286 & 0,349 & 0,160 & 0,502 & 0,244 & 0,569 & 0,486 \\
\hline Avg.-2 & 0,534 & 0,169 & 0,616 & 0,090 & 0,513 & 0,161 & 0,649 & 0,104 & 0,597 & - \\
\hline Avg.IP & $0,406 /$ & 500 & $0,381 /$ & 607 & $0,257 /$ & 486 & $0,445 /($ & 615 & $0,546 / 0$ & 597 \\
\hline
\end{tabular}

Table 4: Average duration of BPs and NBPs with different text localization during NB and FB. The first column contains the participants (n-1 - reading in NB, n-2 - in FB). In the IP line, the average duration of the IPs during NB and FB (NB / FB) is indicated by a "slash" (/). The hyphen ( - ) indicates the absence of an IP. The duration of the pauses was determined in seconds 